\title{
Overview of CSR Practices in Lebanese Commercial Banks
}

\section{Lara Macaron*}

Department of Economics and Business Administration, Lebanese University, Lebanon

Six face to face semi structured interviews were conducted. Two of them were done with CSR experts ((B6) and (B5)) to better understand the evolution of CSR concept in the Lebanese context. And four interviews were conducted with the head of CSR personnel ((B1); (B2); (B3); and (B4)) to better understand the strategies and activities that participant banks adopt for developing their social responsibility, and what are the impact of these activities on the identification and satisfaction of their employees and customers. Each interview was attributed a code. For example, the code "B3" indicates the comment made by the interviewee number three.

The interviews revealed that the corporate's culture in the four banks is strongly supportive and committed to CSR. All CSR managers who were interviewed have CSR policies, have the support of the top management, and integrate CSR into the corporate strategy and align it within the bank core business. One CSR manager stated the following: "CSR strategy [of the bank] was set and linked to the bank's core values that drive the bank and create balance between the company interests and society needs" (B1). In addition, both of CSR experts acknowledge that "the fastest way to be on board is to practice CSR within the core business" (B5, B6), if not, "the bank will not survive" (B6). All banks see that there is a lot of misconception of CSR and people confuse between donation, charity, philanthropy, and CSR (B3), but the transition from philanthropy to CSR for most institutions has been very easy and smoothly converted because the core of CSR exists (B1). One of CSR managers said: "CSR requires banks to only frame, strategize, and put their social activities into a nice set up" (B4). However, CSR expert (B6) mentioned that "some Lebanese banks are on board, but they are doing CSR because they have to do it, it is like a punishment; and maybe these banks are happy because they do CSR but the most important is to see if their social activities have a positive impact on the society especially on their customers and employees".

CSR managers also agreed that the awareness on this topic is quite low at the national level but the level of awareness is improving during the last few years. However, according to one CSR manager (B1) employees and customers are not supposed to know that what 's the bank is doing here and there is CSR, the important thing is that they get the feedback that the bank looks at them as they are part of the community and the environment. "It's not necessary to have a title above every activity that it is a CSR; CSR is not a title, it is a way of life" (B1). It was evident for the four CSR managers that employees are more aware than other stakeholders because they are trained on issues related to CSR especially the ones related to the core business. One CSR manager illustrated that: "I don't think that all CSR issues are something important to customers; customers are interested into CSR activities oriented to them such as transparency, honesty, best products and services, best interest, fast service...... And even when the bank did activities like a plantation day with an NGO, some employees are interested to help planting the trees and some are not...." (B2).

All participant banks announced that the adoption of CSR practices face many challenges at the country level. The bad environmental and economic status of the country, the lack of awareness of the public sector, the lack of regulations and governmental guidelines, the lack of understanding, the lack of business leader engagement, the lack of incentives for medium sized companies to practice CSR, the lack of budget, and the high level of corruption and briberies that are considered as major problems for CSR practices. One CSR manager said: "The greatest obstacle would be the people's adaptability to change and accepting that social responsibility and core business are aligned and one does not necessarily obstruct the other" (B1). The CSR expert (B6) added that the mindset of short term strategies at the level of business executives to generate short-term gains and high returns on investment in the purpose of satisfying shareholders constitutes a big challenge because CSR should be strategized at long term. Furthermore the other CSR expert (B5) mentioned: "If Lebanese business leader does not understand well the concept of CSR, he will consider that any CSR initiatives as something luxurious or expenses while CSR should be from the priority issues of the company".

The participant banks were aware about the fine line between boasting the social responsibility and communicating it. These banks adopted some common communication tools to communicate their CSR initiatives to all their stakeholders such as: Annual CSR report, various awareness sessions at (schools, universities, conferences, forums), mentoring other institutions, press releases, social media, and newsletter and emails communicated through internal channels. However, one CSR manager (B2) argued that: "We don't know how many read the letters and how many don't or how much they are interested to read them, and even we don't think that people will also read the CSR report but we have to do it".

It was evident throughout the 6 interviews that the role of CSR personnels is to embed CSR components in every one's mission to make a difference by reflecting CSR culture in the institution. One CSR manager (B1) clarified that the role of CSR department is a "chef d'orchestre". She said that CSR officers are not supposed to do the activities themselves, they are supposed to orchestrate and account and monitor and measure and assess and report the activities that other departments like HR, PR, marketing, credit, risk, cards, building management, etc... do. She also added that, in some cases, where there is no champion for an initiative due to the load of work in each department, CSR officers can take it and complete it but this doesn't mean that it is right because one day comes and CSR officers will give it again to the correspondent department. But to optimize the social impact, CSR officers cannot work alone without collaborating with other departments if not "the bank will feel the CSR activities as a cost and not as an investment" added CSR manager (B4). CSR manager (B3)

${ }^{*}$ Corresponding author: Lara Macaron, Department of Economics and Business Administration, Lebanese University, Lebanon, Tel: 9613942857; E-mail: Imacaron@hotmail.com

Received January 12, 2018; Accepted January 25, 2018; Published January 29 2018

Citation: Macaron L (2018) Overview of CSR Practices in Lebanese Commercial Banks. Int J Econ Manag Sci 7: 505. doi: 10.4172/2162-6359.1000505

Copyright: (c) 2018 Macaron L. This is an open-access article distributed under the terms of the Creative Commons Attribution License, which permits unrestricted use, distribution, and reproduction in any medium, provided the original author and source are credited. 
mentioned that CSR can further advance the existing practices beyond regulations or beyond respecting legal aspects.

Interviewees named some CSR initiatives they provide including: Special schedule for mothers to establish work life balance, sports and music clubs, human right policy, whistleblowing policy, sustainable procurement policy, paternity leave, training, skills and career development, safety and security conditions, fair compensation, prohibiting discrimination, equal opportunity, transparency, complaining procedures, protecting customer's right, rescheduling corporate loans, donations, sponsoring, financing sustainable programs for NGO, mentoring students, recycling program, reducing energy and paper consumption, green building, integrating disable people, demining program..... CSR manager (B2) added: "We empower the role of woman in the economy to improve the well-being of the society by providing her special loans and facilities, we encourage to grant loans to finance innovative ideas, entrepreneurs and startups, we have a target to reach equality gender at the level of employees and at level of board of directors by $2020 \ldots .$. (B2).

Mainly the four participant banks classify CSR into 4 areas or frameworks: market place (external CSR: customers, suppliers, investors, supply chain....), work place (internal CSR: employees, corporate governance...), environment, and community. To come up with CSR initiatives, banks should look in each area, to be active on all fronts and to see its impact, added CSR expert (B5).

CSR managers also agreed that their respective banks think about the community around them in each region where branches are located. All of the interviewees insist that their respective CSR initiatives oriented to employees and to customers are the same in all branches. They are set by policy. It's nothing to say to privilege one region to another. According to one CSR manager, "our bank doesn't differentiate between the employees or customers of Beirut and Beqaa and even in other region because the bank sells same products and follows same policies and procedures in all branches whatever in Beirut, Beqaa, Mount Lebanon, North, South, and Nabatieh" (B1). Concerning the CSR activities oriented to society, all participant banks aimed to cover all areas of Lebanon; however in Beirut there is more branches, more customers, more employees, more NGO's, more events, more people, so it's logic to have more activities in Beirut more than other region, added CSR manager "B1".

All CSR managers of the participant banks assured that when the company cares about the well-being of their employees, it will increase their level of attachment towards the company, their loyalty, productivity, satisfaction, identification, engagement, commitment, dedication, retention, innovation, creativity, performance... One of
CSR experts (B5) said that "when the employee is satisfied, he will feel that the company is his own company and this we called "employee organization identification". One of CSR managers mentioned that, "CSR activities could increase the sense of belonging of the employee toward its organization" (B2). Another CSR manager (B3) explained that nowadays studies showed that employees are more likely to care about working in a social responsible company even if the salary is below their expectations because they are looking for companies having values similar to their values. In addition, the CSR expert stated the following: "When the company provides the employee with all the facilities, he has to be satisfied and reflect his satisfaction to the client; consequently, an emotional connection could be created between organization, employee and customer" (B5).

All CSR managers of the participant banks supposed that their CSR activities have a positive effect on employee's job satisfaction. One CSR manager said that "CSR is based on job satisfaction" (B1); the low turnover explains why employees don't leave the bank. If someone is not satisfied with his work he will not stay. No body stays in a company if he is not satisfied with a side or other. Another CSR manager (B2) explained that when the bank does "NPS" (a measurement scale for employee and customer satisfaction) after an outing day, the satisfaction will be higher than if the bank does it at the end of the year.

For the CSR manager (B4), customers are more likely to feel good and proud being a customer of a bank that is operating ethically and giving back to the community. In addition, CSR manager (B3) added that customers are in general more attracted and closely linked to an ethically bound company. Also, the CSR manager (B1) explained that: "Lebanese customer's mind didn't reach yet the level to accept paying a penny more for a company that is socially responsible, but if the product was at the same price, he will not think twice, directly he will prefer the socially responsible company" (B1). Furthermore, one of CSR managers (B2) supposed that the CSR activities oriented directly to customer such as "Woman empowerment program" will have definitely an impact on customer satisfaction; Women will feel happy about their decision to choose this bank and they will recommend it to others". However, the CSR manager (B3) doesn't know how his customer perceive the bank CSR activities because the communication towards them still not well done, consequently, she can't predict if there is any impact on customer behavior and attitude.

The above ideas and point of views were the answers and comments of CSR managers of the participant banks and CSR experts regarding their perceptions of CSR concept and perspectives. How strongly these perceptions are practically supported at the level of external and internal customer and whether the CSR activities have any impact on them are yet to be tested. 